\title{
Using literature-based discovery to identify candidate genes for the interaction between myocardial infarction and depression
}

Zhenguo Dai ${ }^{1,2}$, Qian $\mathrm{Li}^{3}$, Guang Yang ${ }^{1,2}$, Yini Wang ${ }^{1,2}$, Yang Liu ${ }^{1,2}$, Zhilei Zheng ${ }^{1,2}$, Yingfeng $\mathrm{Tu}^{1,2}$, Shuang Yang ${ }^{1,2^{*}}$ (D) and Bo $\mathrm{Yu}^{1,2^{*}}$

\begin{abstract}
Background: A multidirectional relationship has been demonstrated between myocardial infarction (MI) and depression. However, the causal genetic factors and molecular mechanisms underlying this interaction remain unclear. The main purpose of this study was to identify potential candidate genes for the interaction between the two diseases.

Methods: Using a bioinformatics approach and existing gene expression data in the biomedical discovery support system (BITOLA), we defined the starting concept X as "Myocardial Infarction" and end concept Z as "Major Depressive Disorder" or "Depressive disorder". All intermediate concepts relevant to the "Gene or Gene Product" for $\mathrm{Ml}$ and depression were searched. Gene expression data and tissue-specific expression of potential candidate genes were evaluated using the Human eFP (electronic Fluorescent Pictograph) Browser, and intermediate concepts were filtered by manual inspection.

Results: Our analysis identified 128 genes common to both the "Ml" and "depression" text mining concepts. Twenty-three of the 128 genes were selected as intermediates for this study, 9 of which passed the manual filtering step. Among the 9 genes, LCAT, CD4, SERPINA1, IL6, and PPBP failed to pass the follow-up filter in the Human eFP Browser, due to their low levels in the heart tissue. Finally, four genes (GNB3, CNR1, MTHFR, and NCAM1) remained.

Conclusions: GNB3, CNR1, MTHFR, and NCAM1 are putative new candidate genes that may influence the interactions between $\mathrm{Ml}$ and depression, and may represent potential targets for therapeutic intervention.
\end{abstract}

Keywords: Myocardial infarction, Depression, BITOLA, Candidate genes, Text mining, Gene expression profiling

\section{Background}

Myocardial infarction (MI) is a highly prevalent cardiovascular disease. The American Heart Association released a scientific statement in 2014 and recommended that depression should be considered a risk factor for adverse medical outcomes in patients with acute coronary syndrome [1]. Depression may cause many adverse outcomes, including autonomic dysfunction [2], inflammation [3], endothelial dysfunction $[4,5]$, hyperactivity of the

\footnotetext{
*Correspondence: dryangshuang@126.com; yubodr@163.com 'Department of Cardiology, The Second Affiliated Hospital of Harbin Medical University, Harbin 150086, China

Full list of author information is available at the end of the article
}

hypothalamic-pituitary-adrenal axis [6], and poor compliance [7], which subsequently lead to an increased risk of MI. Both the severity and cumulative duration of depressive symptoms have a negative impact on the MI prognosis [8]. On the other hand, patients with MI may have a higher prevalence of depression [9]. In an assessment of 10,785 patients with MI performed using a structured clinical interview, depression was common and persistent in MI survivors. Major depression was identified in approximately 1 of $5(19.8 \%)$ patients hospitalized with MI [10]. Thus, understanding the interaction between MI and depression is very important for the development of

(c) The Author(s). 2019 Open Access This article is distributed under the terms of the Creative Commons Attribution 4.0 International License (http://creativecommons.org/licenses/by/4.0/), which permits unrestricted use, distribution, and reproduction in any medium, provided you give appropriate credit to the original author(s) and the source, provide a link to the Creative Commons license, and indicate if changes were made. The Creative Commons Public Domain Dedication waiver (http://creativecommons.org/publicdomain/zero/1.0/) applies to the data made available in this article, unless otherwise stated. 
Search the intermediate concepts relevant to "Gene or Gene Product" using BITOLA

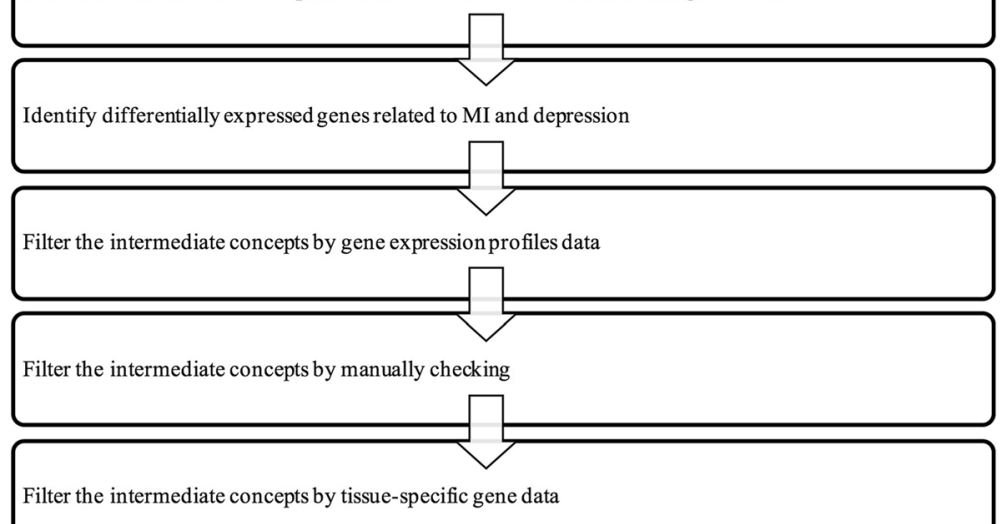

Fig. 1 Flow chart of the study design

Table 1 Description of the $11 \mathrm{Ml}$ and MDD microarray platforms and the gene symbols that overlapped with the CIMs

\begin{tabular}{|c|c|c|c|c|c|c|}
\hline Disease & Series & Tissue & Platform & $\begin{array}{l}\text { Control samples } \\
\text { (n) }\end{array}$ & $\begin{array}{l}\text { Subjects samples } \\
\text { (n) }\end{array}$ & $\begin{array}{l}\text { Gene symbols overlapped with } \\
\text { CIM }\end{array}$ \\
\hline \multirow[t]{4}{*}{ Myocardial Infarction } & GSE48060 & Peripheral blood & GPL570 & 21 & 31 & None \\
\hline & GSE83500 & Aortic wall & GPL13667 & 20 & 17 & $\operatorname{lL}-6$ \\
\hline & GSE97320 & Peripheral blood & GPL570 & 3 & 3 & $\begin{array}{l}\text { HLA-B } \\
\text { PPBP } \\
\text { PTPRC } \\
\text { SERPINA1 }\end{array}$ \\
\hline & GSE61145 & Serum & GPL6106 & 10 & 14 & $\begin{array}{l}\text { RERE } \\
\text { PADI4 }\end{array}$ \\
\hline \multirow{11}{*}{$\begin{array}{l}\text { Major depressive } \\
\text { disorders }\end{array}$} & GSE54562 & anterior cingulate cortex & GPL6947 & 10 & 10 & None \\
\hline & GSE54563 & anterior cingulate cortex & GPL6947 & 25 & 25 & $\begin{array}{l}\text { FCGR3B } \\
\text { LPA }\end{array}$ \\
\hline & GSE54564 & Amygdala & GPL6947 & 21 & 21 & $\begin{array}{l}\text { STAR } \\
\text { ESR1 }\end{array}$ \\
\hline & GSE54565 & anterior cingulate cortex & GPL570 & 16 & 16 & GNB3 \\
\hline & GSE54566 & amygdala & GPL570 & 14 & 14 & None \\
\hline & GSE54567 & $\begin{array}{l}\text { dorsolateral prefrontal } \\
\text { cortex }\end{array}$ & GPL570 & 14 & 14 & $\begin{array}{l}\text { PAG1 } \\
\text { NSF }\end{array}$ \\
\hline & GSE54568 & $\begin{array}{l}\text { dorsolateral prefrontal } \\
\text { cortex }\end{array}$ & GPL570 & 15 & 15 & $\begin{array}{l}\text { ESD } \\
\text { LCAT } \\
\text { DMD }\end{array}$ \\
\hline & GSE54570 & $\begin{array}{l}\text { dorsolateral prefrontal } \\
\text { cortex }\end{array}$ & GPL96 & 13 & 13 & None \\
\hline & GSE54571 & anterior cingulate cortex & GPL570 & 13 & 13 & $\begin{array}{l}\text { AR } \\
\text { CNR1 } \\
\text { CPAMD8 } \\
\text { HLA-B }\end{array}$ \\
\hline & GSE54572 & anterior cingulate cortex & GPL570 & 12 & 12 & $\begin{array}{l}\text { MTHFR } \\
\text { NCAM1 }\end{array}$ \\
\hline & GSE54575 & $\begin{array}{l}\text { orbital ventral prefrontal } \\
\text { cortex }\end{array}$ & GPL96 & 12 & 12 & CD4 \\
\hline
\end{tabular}


therapeutic interventions and determining patients' needs.

The biomedical support discovery system (BITOLA) is a sophisticated bioinformatics tool that enables new discoveries, such as mining new information from the literature without using patient tissue samples, especially for identification of key candidates, and finding potentially new relationships among various biomedical concepts [11, 12]. Some researchers have used the text mining tools to identify candidate genes for diseases [13], such as multiple sclerosis and bilateral polymicrogyria $[12,14,15]$. In addition, using the BITOLA system, genes neural cell adhesion molecule 1 (NCAM1) and CD4 were identified as potential candidate genes in the interaction between depression and oral lichen planus [16].

Because the molecular mechanisms underlying the interaction between MI and depression remain unclear, the aim of the study is to identify new potential candidate genes linking these two diseases.

\section{Methods}

Extracting intermediate concepts from the BITOLA system BITOLA is an interactive, literature-based, biomedical discovery support system (http://arnika.mf.uni-lj. si/pls/bitola2/bitola) [17]. The purpose of the system is to generate new findings by discovering potentially new relationships between biomedical concepts, especially candidate genes that have aetiological relationships with diseases. Currently, the set of concepts in the BITOLA includes Medical Subject Headings (MeSHs), which are utilized to index human genes from the Human Genome Organization (HUGO) and Medline [11]. By mining the Medline database, new information from the literature can be explored to identify new potential candidate genes linked to both MI and depression, and the potential new relationships can be discovered. Flow chart of the study design was shown in Fig. 1.

According to the proposed instructions of the tool, we used a closed discovery system in this study. Briefly, the item "Myocardial infarction" was entered as the starting concept X (Semantic types: disease or syndrome), and the items "Major Depressive Disorder" and "Depressive disorder" were entered as the end concepts Z (semantic types: Mental or Behavioral Dysfunction). Using those concepts, intermediate concepts $\mathrm{Y}$ were examined and extracted. In this study, the semantic types of intermediate concepts mainly referred to the "Gene or Gene Product". Then, the intersection of the two gene sets of related concepts Y (gene or gene product) in total was retrieved for further analysis. These intermediate concepts were defined as the candidate intermediate molecules (CIMs).
Identifying differentially expressed intermediate concepts Next, we tentatively filtered and evaluated the "Gene or Gene Product" by overviewing their mRNA (messenger ribonucleic acid) expression levels under different conditions (MI vs. control or depression vs. control). We reserved differentially expressed "gene or gene product" for the next analysis and excluded non-differentially expressed genes.

\section{Gene expression datasets and statistical analysis}

Gene expression datasets were obtained from the GEO database. The MI datasets used in this study are GSE48060, GSE83500, GSE97320, and GSE61145. GSE48060 was developed from the PBMCs of 52 patients diagnosed with MI and normal controls [18]. The GSE83500 dataset was developed from the aortic wall of MI patients and healthy individuals. GSE97320 and GSE61145 were developed from the peripheral blood from 6 and sera from 24 MI patients and normal controls. [19]. The depression datasets used in this

Table 2 Differentially expressed gene or gene product suggested by the closed BITOLA system

\begin{tabular}{|c|c|c|c|}
\hline Gene or gene product & FreqXY & FreqYZ & Freq $X Y^{*}$ Freq $Y Z$ \\
\hline LPA & 1 & 1 & 1 \\
\hline FCGR3B & 2 & 7 & 14 \\
\hline STAR & 4 & 1 & 4 \\
\hline ESR1 & 3 & 2 & 6 \\
\hline GNB3 & 4 & 1 & 4 \\
\hline PAG1 & 1 & 1 & 1 \\
\hline NSF & 1 & 1 & 1 \\
\hline ESD & 1 & 1 & 1 \\
\hline LCAT & 1 & 1 & 1 \\
\hline DMD & 3 & 1 & 3 \\
\hline AR & 2 & 1 & 2 \\
\hline CNR1 & 1 & 2 & 2 \\
\hline CPAMD8 & 2 & 4 & 8 \\
\hline HLA-B & 1 & 1 & 1 \\
\hline MTHFR & 40 & 4 & 160 \\
\hline CD4 & 11 & 16 & 176 \\
\hline IL6 & 99 & 20 & 1980 \\
\hline RERE & 1 & 1 & 1 \\
\hline PADI4 & 1 & 1 & 1 \\
\hline SERPINA1 & 1 & 1 & 1 \\
\hline PTPRC & 8 & 1 & 8 \\
\hline PPBP & 4 & 1 & 4 \\
\hline NCAM1 & 1 & 7 & 7 \\
\hline
\end{tabular}

Freq Frequency of co-occurrence of two concepts in literature, $X$ starting concept "Myocardial infarction" Z: end concept "Major Depressive Disorder" or "Depressive disorder" 
study are GSE54562, GSE54563, GSE54564, GSE54565, GSE54566, GSE54567, GSE54568, GSE54570, GSE54571, GSE54572, and GSE54575 [20].

All GEO datasets were obtained from the GEO NCBI database, and the DEGs between the case group and the normal controls were analysed using the integrated GEO2R tool [21, 22]. Samples were assigned within a GEO series as either a normal control or case group depending upon the sample source and experimental classification. A T-test was used to sort out the DEGs. Multiple testing was applied using the Benjamini and Hochberg false discovery rate method. GEO2R provides a list of all probes (and corresponding gene aliases) ranked according to their degrees of differential expression. The top 250 probes were selected for the subsequent analysis, and finally the probes were converted into gene names.

\section{Manual checking of the intermediate concepts}

False-positive genes may be identified during literature mining, and manually checking is a precise method to recognize these genes. We manually checked the gene symbols in the co-occurrence literature together with MI and depression and excluded the ambiguous terms that could apply to other topics.

\section{Evaluating expression patterns of the remaining "gene or gene product"}

After manually checking the intermediate concepts, the remaining "Gene or Gene Product" were further filtered based on tissue-specific expression. For inclusion as candidate genes for the interaction of MI and depression, the genes from the list had to show a specific pattern of expression in both the heart and brain tissue; genes that did not satisfy the conditions were excluded. The Human eFP ("electronic Fluorescent Pictograph") Browser (http://bar.utoronto.ca/efp_human/) was used to rapidly interpret the gene expression profiles; this program enables the user to easily visualize large-scale data sets based on representations of the human body [23]. In the gene expression profiling studies, the gene symbol was entered, the "Absolute" mode was chosen for interpretation, and the "Nervous" or the "Circulatory Respiratory" data source was selected. After clicking "Go", the representations of human samples are

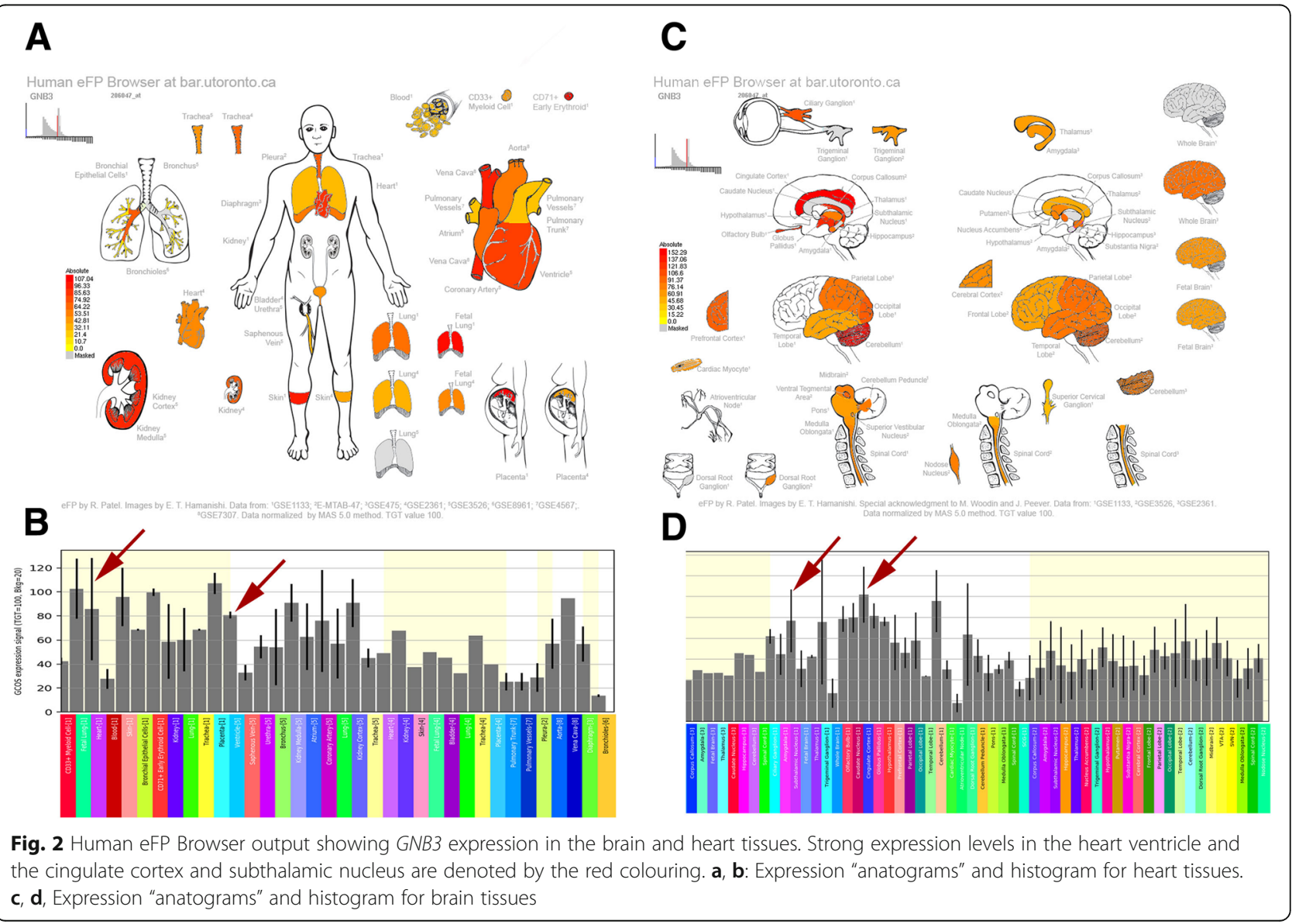




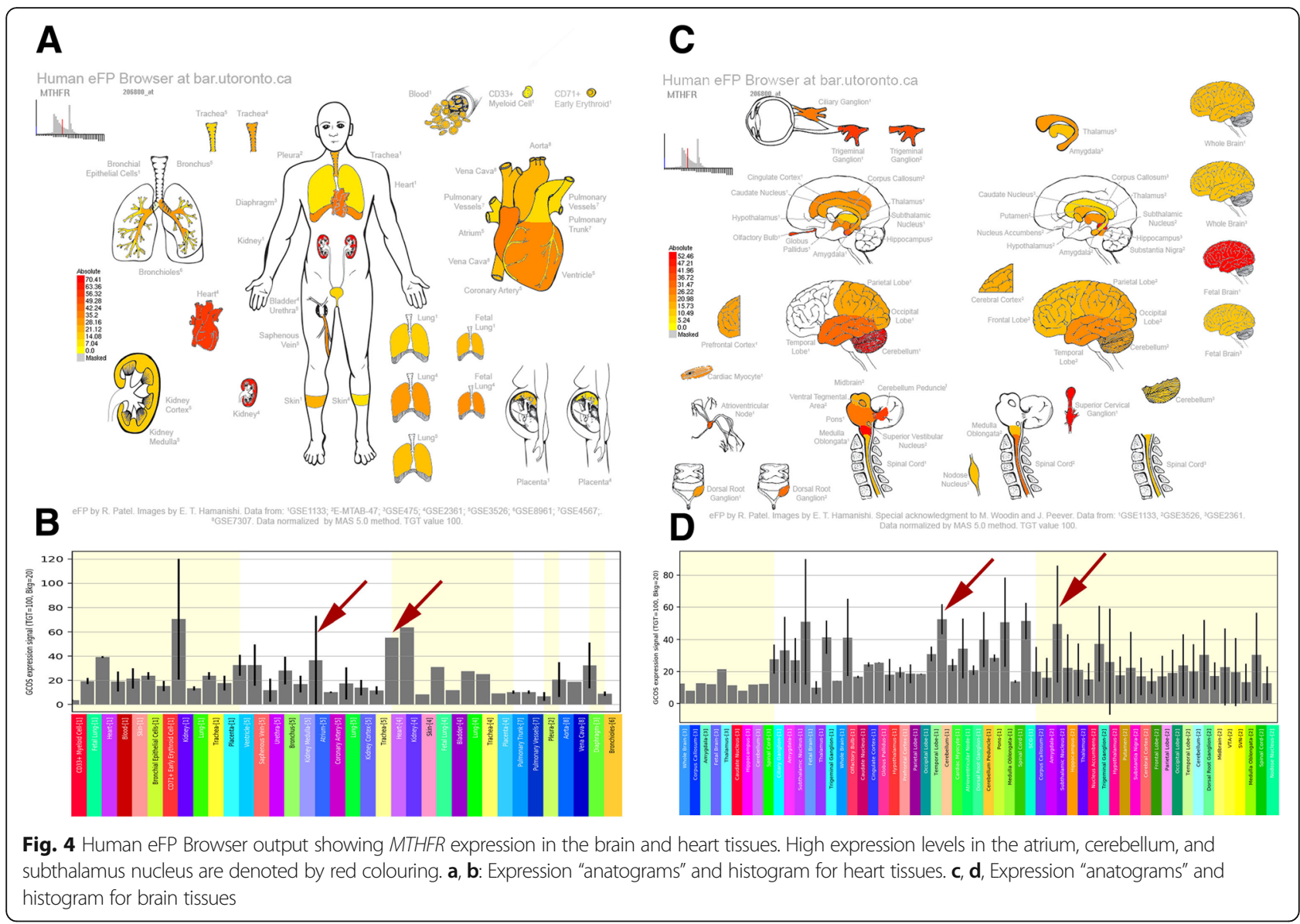

coloured based on the expression level of the gene of interest to generate expression "anatograms" for rapid interrogation. Using this procedure, we can determine whether the given "Gene or Gene Product" is most strongly expressed in the heart or brain tissue. A yellowred scale is used depict the expression levels, with yellow denoting no expression in a given depiction of a tissue and red denoting maximal expression [23].

\section{Results}

Intermediate concepts relevant to "Gene or Gene

Product" for MI and depression

Using the adapted discovery algorithm with the starting concept $\mathrm{X}$ and end concept $\mathrm{Z}$ and its integration into the closed BITOLA system, we searched the entire intermediate concept Y relevant to "Gene or Gene Product". We defined the starting concept $X$ as "Myocardial Infarction" and end concept $\mathrm{Z}$ as "Major Depressive Disorder" or "Depressive disorder". In this manner, 72 and 111 "gene or gene product" were suggested by the closed BITOLA system with the starting concept "Myocardial Infarction" and the end concepts "Major Depressive Disorder" and "Depressive disorder", respectively. The intersection of the two gene sets of 128 related concepts $\mathrm{Y}$ (gene or gene product) in total was selected for further analysis, and we defined these selected genes as the CIMs.

Genes differentially expressed in both $\mathrm{MI}$ and depression Analysis of the GSE48060, GSE83500, GSE97320, and GSE61145 for MI, GSE54562, GSE54563, GSE54564, GSE54565, GSE54566, GSE54567, GSE54568, GSE54570, GSE54571, GSE54572, and GSE54575 data sets for major depressive disorders obtained from the Gene Expression Omnibus (GEO) revealed 2750 differentially expressed genes (DEGs). After contrastive analysis, seven genes (IL-6, HLA-B, PPBP, PTPRC, SERPINA1, RERE, and PADI4) were found to overlap between the 128 CIMs and the DEGs from GSE83500, GSE97320, and GSE61145. Meanwhile, sixteen genes (FCGR3B, LPA, STAR, ESR1, GNB3, PAG1, NSF, ESD, LCAT, DMD, AR, CNR1, CPAMD8, HLA-B, MTHFR, and NCAM1) overlapped between the 128 CIMs and the DEGs from GSE54563, GSE54564, GSE54565, GSE54567, GSE54568, GSE54571, and GSE54572 (Table 1). We further explored the correlations between MI and depression by defining the overlap between the DEGs and the 128 CIMs (Tables 1 and 2). 


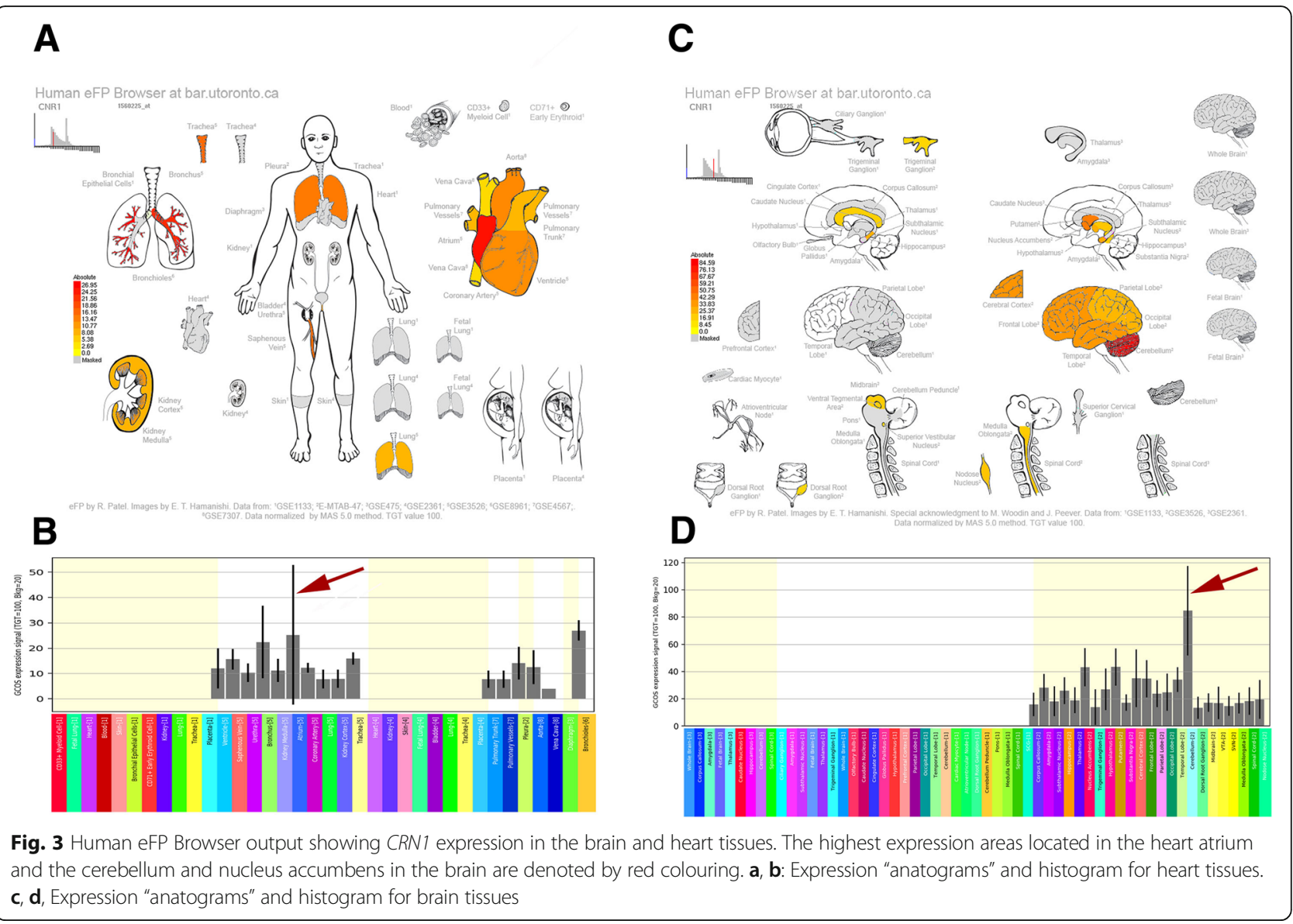

To remove the genes that were not the original ideas for the "gene or gene product", we used the most precise method, manual checking, to evaluate the abbreviations or the alternative names for these genes used in the literatures. Fourteen genes (FCGR3B, STAR, ESR1, PAG1, NSF, ESD, $D M D, A R, C P A M D 8, H L A-B, R E R E, P A D I 4, P T P R C$, and $L P A$ ) failed to pass the follow-up manual literature mining inspection due to ambiguous terms aroused by the defects in the literature mining itself and thus were removed from further analysis.

\section{Common gene expression patterns in heart and brain tissues}

In the analysis, we examined the gene expression patterns of the remaining genes by using the Human eFP Browser [23], which provides an overview of gene expression levels in the heart and brain. $L C A T, C D 4, S E R$ PINA1, IL6, and PPBP failed to pass the follow-up filter, partly because these genes were not preferentially expressed in the heart tissue, which is the target of MI. Based on the tissue-specific expression patterns of the remaining genes, GNB3, CNR1, MTHFR, and NCAM1 were chosen as potential candidate genes for further analysis (Fig. 2, 3, 4, 5) . The analysis showed that GNB3 was highly expressed in the heart ventricle and cingulate cortex of the brain (Fig. 2). CRN1 showed the highest expression in the heart atrium and cerebellum and nucleus accumbens of the brain (Fig. 3) . Furthermore, MTHFR was overexpressed in the heart atrium and cerebellum and subthalamus nucleus of the brain (Fig. 4). Figure 5 shows the NCAM1 gene, which has high expression in the heart atrium and cerebral cortex and amygdala of the brain. Taken together, these results suggest that the overexpression of the GNB3, CNR1, MTHFR, and NCAM1 genes may contribute to the development of MI and depression and may play a role in the interaction between these two diseases.

\section{Discussion}

In this study, we present for the first time a preliminary literature mining work exploring candidate genes related to $\mathrm{MI}$ and depression. By integrating data from the literature, we revealed 4 genes of interest (GNB3, CNR1, MTHFR, and NCAM1) that were likely to be associated with the aetiology of both MI and depression.

$\mathrm{G}$ proteins play an important role in intracellular signal transduction from the cell surface [24]. A C3T polymorphism at nucleotide 825 in exon 10 of the $\mathrm{G}$ protein $\beta 3$ subunit gene (GNB3/C825T) was demonstrated to be 


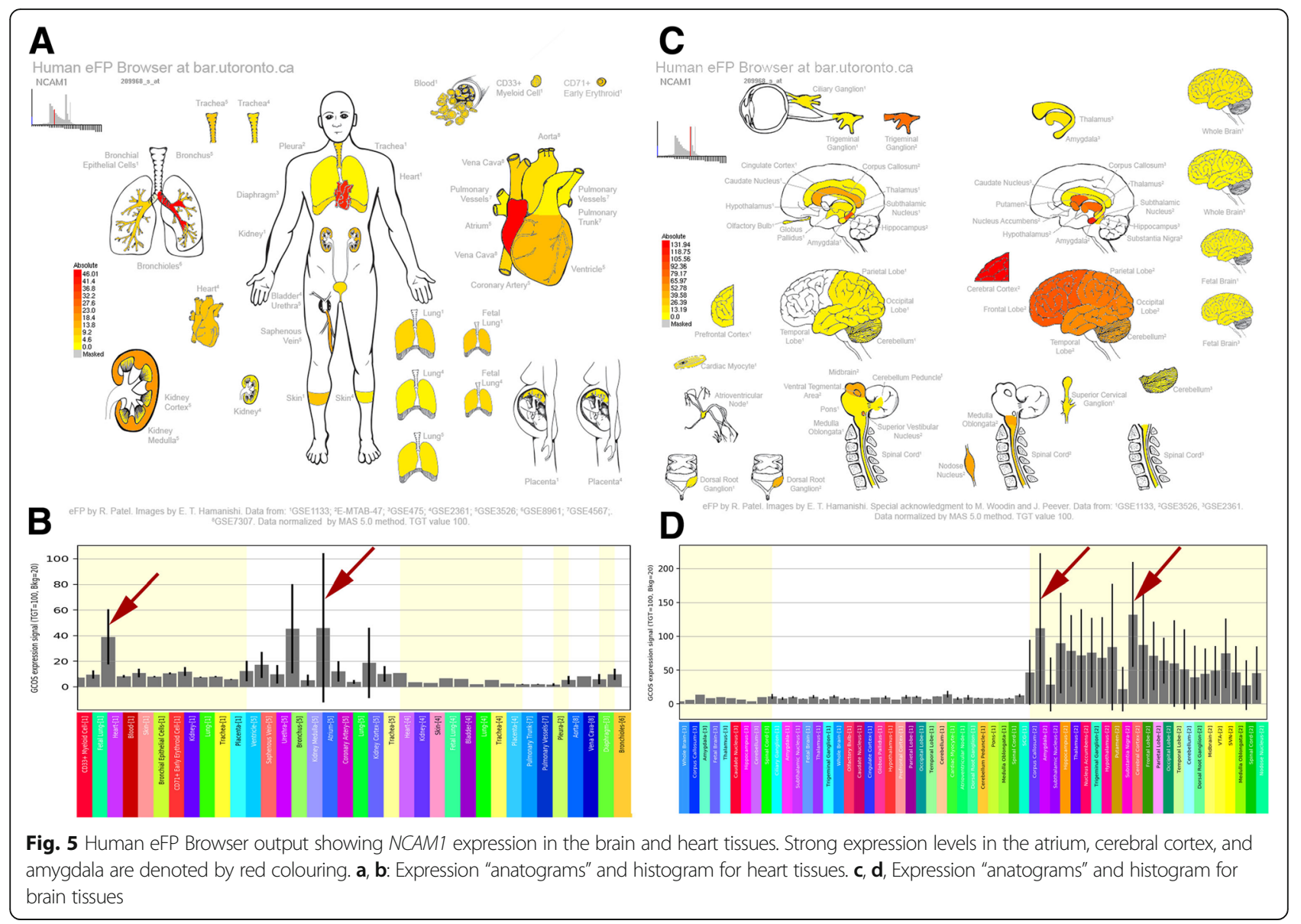

associated with enhanced intracellular signal transduction [25] and a variety of cardiovascular risk factors, including hypertension [25], obesity [26], dyslipidaemia [27], diabetes, and atherosclerosis [28]. An association between GNB3/C825T and MI has also been reported [29]. In addition to the roles mentioned above, studies have implicated a role for GNB3/C825T in depressive disorder [30-32] and the efficacy of antidepressants for the treatment of major depression disorders [33]. In the present study, we found the highest GNB3 expression in the heart ventricle and cingulate cortex of the brain (Fig. 2), which was in accordance with the aetiology of depression [34] . Thus, further study of GNB3 is essential for assessment of the interaction between $\mathrm{MI}$ and depression.

Cannabinoid receptor 1 (CNR1) is one member of the seven transmembrane G-protein coupled receptor family and can regulate the levels of second messenger mainly through coupling with $G$ proteins after activation by endocannabinoids $[35,36]$. The CNR1 receptor may play a protective role through a wide variety of mechanisms, including inhibition of excessive noradrenaline release from the sympathetic nerve fibres [37], lowering inflammation, oxidative stress, fibrosis, and excitotoxicity, and enhancing blood flow [38]. Therefore, cannabinoid receptor agonists can be considered as a prospective group of compounds for creation of drugs that are able to protect the heart against ischaemia-reperfusion injury in the clinical setting [39]. Over the past few years, numerous studies have suggested that depression directly results in the hyperactivity of the hypothalamicpituitary-adrenal axis [6]. Studies have also suggested that CNR1 negatively regulates the hypothalamicpituitary-adrenal axis function [40, 41]. In addition, mice lacking CNR1 can develop depressive-like behaviours or disorders [42]. Specifically, in our study, high CNR1 expression in the brain areas was observed at the nucleus accumbens (Fig. 3), which has been suggested to be related to a lack of interest and other symptoms of depression [43]. The evidence above suggests that targeting the endocannabinoid system may evolve as a novel therapeutic concept to limit the devastating consequences of MI and depression.

Methylenetetrahydrofolate reductase (MTHFR) is a key enzyme involved in homocysteine metabolism. An elevated total plasma homocysteine level has been demonstrated to be associated with both cardiovascular disease and depression $[44,45]$. Because the $\mathrm{C}$-to- $\mathrm{T}$ transition can cause reduced enzyme activity and elevated total plasma 
homocysteine levels, a positive relationship may exist between the MTHFR $677 \mathrm{C} \rightarrow \mathrm{T}$ polymorphism and these two diseases, which has also been demonstrated $[46,47]$. This polymorphism was also associated with a risk of MI $[48,49]$. Moreover, the results confirmed those of very recent meta-analyses of genome-wide association studies, suggesting that MTHFR was a genetic overlap candidate gene that likely was shared between mood disorders and cardiovascular diseases [50]. These findings provide some concrete directions for further research.

NCAM1, which is also known as CD56, is a member of the immunoglobulin superfamily [51]. NCAM1 was first identified in brain tissue and is the best surface antigen for identification of human NK cells [52]. Numerous studies have suggested that NCAM1 is a gene of interest associated with the pathogenesis of depressive disorder [52-54]. Experimental evidence showed that NCAM deficiency in mice resulted in a depression-like phenotype that could be reversed by an NCAM-derived peptide [55]. In the present study, the NCAM1 gene was mainly expressed in the cerebral cortex and amygdala in the brain (Fig. 5), which are involved in the pathogenesis of depression [56]. In addition to its role in depression, studies have also suggested its correlations with MI [57]. One study demonstrated that NCAM1 was upregulated under metabolic stress in cardiomyocytes and suggested that NCAM1 was a cardioprotective factor [58]. Hence, this evidence may have implications for the role of NCAM1 in communication between MI and depression that warrants further exploration.

\section{Conclusion}

In conclusion, using literature mining methods, the GNB3, CNR1, MTHFR, and NCAM1 genes were identified and directly or indirectly implicated in the regulation of MI and depression. Although additional research is needed to confirm these findings, our study reduced the candidate causal genes to a manageable number and might present potential new clues for future research.

\begin{abstract}
Abbreviations
BITOLA: Biomedical discovery support system; CIM: Candidate intermediate molecule; CNR1: Cannabinoid receptor 1; DEGs: Differentially expressed genes; GEO: Gene Expression Omnibus; GNB3: G protein $\beta 3$ subunit gene; MI: Myocardial infarction; MTHFR: Methylenetetrahydrofolate reductase; NCAM1: Neural cell adhesion molecule 1
\end{abstract}

\section{Acknowledgements}

We thank Professor Bo Wang from the University of Lethbridge for reviewing our study. We thank Di Wang for language editing of this paper.

\section{Authors' contributions}

Conceptualization, ZD and QL; Interpretation of data, QL and GY; Formal analysis, YL; Funding acquisition, SY and BY; Methodology, ZD and ZZ; Software, YW and YT; Writing - original draft, ZD; Writing - review \& editing, SY and BY. All authors read and approved the final manuscript.

\section{Funding}

Dr. Yang is supported by the Key Laboratory of Myocardial Ischemia, Harbin Medical University, Chinese Ministry of Education (KF201604 and KF201519). $\mathrm{Dr}$. Tu is supported by the National Natural Science Foundation of China (81671746 and 81401457) and the Special Financial Grant from the China Postdoctoral Science Foundation (2016 T90313). Dr. Yu is supported by the National Natural Science Foundation of China (81330033) and the National Key R\&D Program of China (2016YFC1301100). These funding sources play roles in the interpretation of data and in writing the manuscript for publication.

Availability of data and materials

The data are available at: http://arnika.mf.uni-lj.si/pls/bitola2/bitola and http://bar.utoronto.ca/efp_human/.

Ethics approval and consent to participate

Not applicable.

\section{Consent for publication}

Not applicable.

\section{Competing interests}

The authors declare that they have no competing interests.

\section{Author details}

${ }^{1}$ Department of Cardiology, The Second Affiliated Hospital of Harbin Medical University, Harbin 150086, China. ${ }^{2}$ The Key Laboratory of Myocardial Ischemia, Harbin Medical University, Ministry of Education, Harbin, China.

${ }^{3}$ Department of Neurology, The Second Affiliated Hospital of Harbin Medical University, Harbin 150086, China.

Received: 6 December 2018 Accepted: 4 June 2019

Published online: 11 June 2019

\section{References}

1. Lichtman JH, Froelicher ES, Blumenthal JA, Carney RM, Doering LV, Frasuresmith N, Freedland KE, Jaffe AS, Leifheitlimson EC, Sheps DS. Depression as a risk factor for poor prognosis among patients with acute coronary syndrome: systematic review and recommendations: a scientific statement from the American Heart Association. Circulation. 2014;129(12):1350-69.

2. Carney RM, Saunders RD, Freedland KE, Stein P, Rich MW, Jaffe AS. Association of depression with reduced heart rate variability in coronary artery disease. Am J Cardiol. 1995;76(8):562-4.

3. Pan $Y$, Chen X-Y, Zhang Q-Y, Kong L-D. Microglial NLRP3 inflammasome activation mediates IL-1 $\beta$-related inflammation in prefrontal cortex of depressive rats. Brain Behav Immun. 2014;41:90-100.

4. Wagner J, Tennen H, Mansoor G, Abbott G. Endothelial dysfunction and history of recurrent depression in postmenopausal women with type 2 diabetes: a case-control study. J Diabetes Complications. 2009;23(1):18-24.

5. Harris KF, Matthews KA, Suttontyrrell K, Kuller LH. Associations between psychological traits and endothelial function in postmenopausal women. Psychosom Med. 2003;65(3):402-9.

6. Rybakowski JK, Twardowska K. The dexamethasone/corticotropin-releasing hormone test in depression in bipolar and unipolar affective illness. J Psychiatr Res. 1999;33(5):363.

7. Carney RM, Freedland KE, Eisen SA, Rich MW, Jaffe AS. Major depression and medication adherence in elderly patients with coronary artery disease. Health Psychol. 1995;14(1):88-90.

8. Meijer A, Conradi HJ, Bos EH, Anselmino M, Carney RM, Denollet J, Doyle F, Freedland KE, Grace SL, Hosseini SH. Adjusted prognostic association of depression following myocardial infarction with mortality and cardiovascular events: individual patient data meta-analysis. Br J Psychiatry. 2013;203(2):90-102.

9. Gonzalez MB, Snyderman TB, Colket JT, Arias RM, Jiang JW, O'Connor CM, Krishnan KR. Depression in patients with coronary artery disease. Depression. 1996;4(2):57-62.

10. Thombs BD, Bass EB, Ford DE, Stewart KJ, Tsilidis KK, Patel U, Fauerbach JA, Bush DE, Ziegelstein RC. Prevalence of depression in survivors of acute myocardial infarction: review of the evidence. J Gen Intern Med. 2006;21(1):30-8. 
11. Hristovski D, Friedman C, Rindflesch TC, Peterlin B. Exploiting semantic relations for literature-based discovery. In: AMIA Annu Symp Proc, vol. 2006; 2006. p. 349

12. Hristovski D, Peterlin B, Mitchell JA, Humphrey SM. Improving literature based discovery support by genetic knowledge integration. Stud Health Technol Inform. 2003;95:68-73.

13. Karić A, Karić A. Using the BITOLA system to identify candidate genes for Parkinson's disease. Bosn J Basic Med Sci. 2011;11(3):185-9.

14. Hristovski D, Peterlin B, Dzeroski S. Literature based discovery support system and its application to disease gene identification. In: Computational discovery of scientific knowledge; 2007. p. 307-26.

15. Hristovski D, Stare J, Peterlin B, Dzeroski S. Supporting discovery in medicine by association rule mining in Medline and UMLS. Stud Health Technol Inform. 2001;84(2):1344-8.

16. Zhan Y, Zhou S, Li Y, Mu S, Zhang R, Song X, Lin F, Zhang B. Using the BITOLA system to identify candidate molecules in the interaction between oral lichen planus and depression. Behav Brain Res. 2017;320:136-42.

17. Hristovski D, Peterlin B, Mitchell JA, Humphrey SM. Using literature-based discovery to identify disease candidate genes. Int J Med Inform. 2005;74(2-4):289-98.

18. Suresh R, Xing L, Chiriac A, Goel K, Terzic A, Perezterzic C, Nelson TJ. Transcriptome from circulating cells suggests dysregulated pathways associated with long-term recurrent events following first-time myocardial infarction. J Mol Cell Cardiol. 2014;74(3):13.

19. Park HJ, Noh JH, Eun JW, Koh YS, Seo SM, Park WS, Lee JY, Chang K, Seung KB, Kim PJ. Assessment and diagnostic relevance of novel serum biomarkers for early decision of ST-elevation myocardial infarction. Oncotarget. 2015;6(15):12970-83.

20. Chang LC, Jamain S, Lin CW, Rujescu D, Tseng GC, Sibille E. A conserved BDNF, glutamate- and GABA-enriched gene module related to human depression identified by coexpression meta-analysis and DNA variant genome-wide association studies. PLoS One. 2014;9(3):e90980.

21. Barrett T, Troup DB, Wilhite SE, Ledoux P, Evangelista C, Kim IF, Tomashevsky M, Marshall KA, Phillippy KH, Sherman PM. NCBI GEO: archive for functional genomics data sets--10 years on. Nucleic Acids Res. 2011; 39(Database issue:1005-10.

22. Barrett T, Wilhite SE, Ledoux P, Evangelista C, Kim IF, Tomashevsky M, Marshall KA, Phillippy KH, Sherman PM, Holko M. NCBI GEO: archive for functional genomics data sets-update. Nucleic Acids Res. 2013; 41(Database issue):D991.

23. Patel RV, Hamanishi ET, Provart NJ. A human "eFP" browser for generating gene expression Anatograms. PLoS One. 2016;11(3):e0150982.

24. Siffert W. G-protein beta3 subunit $825 \mathrm{~T}$ allele and hypertension. Curr Hypertens Rep. 1999;34(5):47-53.

25. Siffert W, Rosskopf D, Siffert G, Busch S, Moritz A, Erbel R, Sharma AM, Ritz E, Wichmann HE, Jakobs KH. Association of a human G-protein beta3 subunit variant with hypertension. Nat Genet. 1998;18(1):45-8.

26. Casiglia E, Tikhonoff V, Caffi S, Martini B, Guidotti F, Bolzon M, Bascelli A, D'Este D, Mazza A, Pessina AC. Effects of the C825T polymorphism of the GNB3 gene on body adiposity and blood pressure in fertile and menopausal women: a population-based study. J Hypertens. 2008;26(2):238-43.

27. Hayakawa T, Takamura T, Abe T, Kaneko S. Association of the C825T polymorphism of the G-protein beta3 subunit gene with hypertension, obesity, hyperlipidemia, insulin resistance, diabetes, diabetic complications, and diabetic therapies among Japanese. Metabolism. 2007;56(1):44.

28. Siffert W. G protein polymorphisms in hypertension, atherosclerosis, and diabetes. Annu Rev Med. 2005;56(1):17.

29. Chang WT, Wang YC, Chen CC, Zhang SK, Liu CH, Chang FH, Hsu LS. The $-308 \mathrm{G} / \mathrm{a}$ of tumor necrosis factor (TNF)- $a$ and $825 \mathrm{C} / \mathrm{T}$ of guanidine nucleotide binding protein 3 (GNB3) are associated with the onset of acute myocardial infarction and obesity in Taiwan. Int J Mol Sci. 2012;13(2):1846

30. Kunugi H, Kato T, Fukuda R, Tatsumi M, Sakai T, Nanko S. Association study of C825T polymorphism of the G-protein b3 subunit gene with schizophrenia and mood disorders. J Neural Transm. 2002;109(2):213-8.

31. Lin CN, Tsai SJ, Hong CJ. Association analysis of a functional G protein beta3 subunit gene polymorphism (C825T) in mood disorders. Neuropsychobiology. 2001;44(3):118.
32. Ma J, Wang L, Yang Y, Qiao Z, Fang D, Qiu X, Yang X, Zhu X, He J, Pan H. GNB3 and CREB1 gene polymorphisms combined with negative life events increase susceptibility to major depression in a Chinese Han population. PLoS One. 2017:12(2):e0170994.

33. Hu Q, Zhang SY, Liu F, Zhang XJ, Cui GC, Yu EQ, Xu XF, Li P, Xiao JQ, Wei DM. Influence of GNB3 C825T polymorphism on the efficacy of antidepressants in the treatment of major depressive disorder: a metaanalysis. J Affect Disord. 2015;172:103-9.

34. Greicius MD, Flores BH, Menon V, Glover GH, Solvason HB, Kenna H, Reiss AL, Schatzberg AF. Resting-state functional connectivity in major depression: abnormally increased contributions from Subgenual cingulate cortex and thalamus. Biol Psychiatry. 2007;62(5):429-37.

35. Howlett AC. The cannabinoid receptors. Prostaglandins \& Other Lipid Mediators. 2002;69(2):619-31.

36. Mackie K. Cannabinoid receptors: where they are and what they do. J Neuroendocrinol. 2008;20(1):10-4

37. Rudź R, Schlicker E, Baranowska U, Marciniak J, Karabowicz P, Malinowska B. Acute myocardial infarction inhibits the neurogenic tachycardic and vasopressor response in rats via presynaptic cannabinoid type 1 receptor. J Pharmacol Exp Ther. 2012;343(1):198-205.

38. Tuma RF, Steffens S. Targeting the endocannabinod system to limit myocardial and cerebral ischemic and reperfusion injury. Curr Pharm Biotechnol. 2012;13(1):46-58.

39. Maslov LN, Khaliulin I, Zhang Y, Krylatov AV, Naryzhnaya NV, Mechoulam R, Petrocellis L, Downey JM. Prospects for creation of Cardioprotective drugs based on cannabinoid receptor agonists. J Cardiovasc Pharmacol Ther. 2016;21(3):262-72. https://journals.sagepub.com/doi/abs/10.1177/ 1074248415612593

40. Patel S, Roelke CT, Rademacher DJ, Cullinan WE, Hillard CJ. Endocannabinoid signaling negatively modulates stress-induced activation of the hypothalamicpituitary-adrenal Axis. Endocrinology. 2004;145(12):5431-8.

41. Cota D, Steiner MA, Marsicano G, Cervino C, Herman JP, Grübler Y, Stalla J, Pasquali R, Lutz B, Stalla GK. Requirement of cannabinoid receptor type 1 for the basal modulation of hypothalamic-pituitary-adrenal axis function. Endocrinology. 2007;148(4):1574-81.

42. Valverde $\mathrm{O}$, Torrens M. CB1 receptor-deficient mice as a model for depression. Neuroscience. 2012;204:193-206.

43. Robbe D, Kopf M, Remaury A, Bockaert J, Manzoni OJ. Endogenous cannabinoids mediate long-term synaptic depression in the nucleus accumbens. Proc Natl Acad Sci U S A. 2002;99(12):8384

44. Bottiglieri T, Laundy M, Crellin R, Toone BK, Carney MW, Reynolds EH. Homocysteine, folate, methylation, and monoamine metabolism indepression. J Neurol Neurosurg Psychiatry. 2000;69(2):228-32.

45. Mehlig K, Leander K, Faire UD, Nyberg F, Berg C, Rosengren A, Björck L, Zetterberg $\mathrm{H}$, Blennow $\mathrm{K}$, Tognon $\mathrm{G}$. The association between plasma homocysteine and coronary heart disease is modified by the MTHFR 677C>T polymorphism. Heart. 2013;99(23):1761-5.

46. Arinami T, Yamada N, Yamakawa-Kobayashi K, Hamaguchi H, Toru M. Methylenetetrahydrofolate reductase variant and schizophrenia/depression. Am J Med Genet A. 1997;74(5):526-8.

47. Bjelland I, Tell GS, Vollset SE, Refsum H, Ueland PM. Folate, vitamin B12, homocysteine, and the MTHFR $677 \mathrm{C}->$ T polymorphism in anxiety and depression: the Hordaland homocysteine study. Arch Gen Psychiatry. 2003;60(6):618-26

48. Alizadeh S, Djafarian K, Moradi S, Shab-Bidar S. C667T and A1298C polymorphisms of methylenetetrahydrofolate reductase gene and susceptibility to myocardial infarction: a systematic review and metaanalysis. Int J Cardiol. 2016;217:99-108.

49. Kozieradzka A, Pepinski W, Waszkiewicz E, Olszewska M, Maciorkowska D, Skawronska M, Niemcunowicz-Janica A, Dobrzycki S, Musial WJ, Kaminski KA. The rs 1801133 polymorphism of methylenetetrahydrofolate reductase gene- the association with 5-year survival in patients with ST-elevation myocardial infarction. Adv Med Sci. 2012;57(1):106-11.

50. Amare AT, Schubert KO, Klinglerhoffmann M, Cohenwoods S, Baune BT. The genetic overlap between mood disorders and cardiometabolic diseases: a systematic review of genome wide and candidate gene studies. Transl Psychiatry. 2017;7(1):e1007.

51. Walsh FS, Doherty P. Neural cell adhesion molecules of the immunoglobulin superfamily: role in axon growth and guidance. Annu Rev Cell Dev Biol. 2003:104(13):425-56. 
52. Lanier LL, Testi R, Bindl J, Phillips JH. Identity of Leu-19 (CD56) leukocyte differentiation antigen and neural cell adhesion molecule. J Exp Med. 1989;169(6):2233-8.

53. Atz ME, Rollins B, Vawter MP. NCAM1 association study of bipolar disorder and schizophrenia: polymorphisms and alternatively spliced isoforms lead to similarities and differences. Psychiatr Genet. 2007;17(2):55.

54. Petrovska J, Coynel D, Fastenrath M, Milnik A, Auschra B, Egli T, Gschwind L, Hartmann F, Loos E, Sifalakis K. The NCAM1 gene set is linked to depressive symptoms and their brain structural correlates in healthy individuals. J Psychiatr Res. 2017;91:116.

55. Aonurm-Helm A, Jurgenson M, Zharkovsky T, Sonn K, Berezin V, Bock E, Zharkovsky A. Depression-like behaviour in neural cell adhesion molecule (NCAM)-deficient mice and its reversal by an NCAM-derived peptide, FGL. Eur J Neurosci. 2008;28(8):1618.

56. John CS, Sypek El, Carlezon WA, Cohen BM, Öngür D, Bechtholt AJ. Blockade of the GLT-1 transporter in the central nucleus of the amygdala induces both anxiety and depressive-like symptoms.

Neuropsychopharmacology. 2015;40(7):1700.

57. Gattenlöhner S, Waller C, Ertl G, Bültmann BD, Müllerhermelink HK, Marx A. NCAM(CD56) and RUNX1(AML1) are up-regulated in human ischemic cardiomyopathy and a rat model of chronic cardiac ischemia. Am J Pathol. 2003;163(3):1081-90.

58. Nagao K, Ono K, Iwanaga Y, Tamaki Y, Kojima Y, Horie T, Nishi H, Kinoshita M, Kuwabara Y, Hasegawa K. Neural cell adhesion molecule is a cardioprotective factor up-regulated by metabolic stress. J Mol Cell Cardiol. 2010;48(6):1157-68.

\section{Publisher's Note}

Springer Nature remains neutral with regard to jurisdictional claims in published maps and institutional affiliations.

Ready to submit your research? Choose BMC and benefit from:

- fast, convenient online submission

- thorough peer review by experienced researchers in your field

- rapid publication on acceptance

- support for research data, including large and complex data types

- gold Open Access which fosters wider collaboration and increased citations

- maximum visibility for your research: over $100 \mathrm{M}$ website views per year

At $\mathrm{BMC}$, research is always in progress.

Learn more biomedcentral.com/submissions 